\title{
CO-DETERMINATION AND APPRENTICESHIP IN SME: A QUALITATIVE STUDY ON WORK COUNCILS AND THEIR CONTRIBUTION TO THE QUALITY OF APPRENTICESHIP TRAINING
}

\author{
Christiane Eberhardt ${ }^{1}$, Klaus Berger ${ }^{2}$ \\ 1 Senior Expert „International VET in comparison“ Federal Institute for Vocational Education and Training, \\ Germany, e-mail: Eberhardt@bibb.de \\ 2 Researcher Federal Institute for Vocational Education and Training, Germany (retired), \\ e-mail: bergklau@t-online.de
}

\begin{abstract}
:
Relevance. Training systems which are based on the principle of apprenticeship and involve the company as a central venue are gaining in significance in international terms. The fundamental recognition here is, "Apprenticeships as one successful form of work-based learning ease the transition from education and training to work, and evidence suggests that countries with a strong VET and apprenticeship system have lower levels of youth unemployment" (European Commission, year of publication not stated).

Aim: the purpose of the article is to prove that the competitiveness of companies on the market crucially depends on their skilled workers.

Methods: in methodological terms, we based our study on an industrial sociology case study approach.

Results: in our study we showed that the stakeholders at the companies forming the object of our investigations are working towards quality. If the high quality requirements of training are also to be realised at a company level, crucial significance needs to be attached to the central players within the company. In our case, these are the works councils.

Conclusions: in our study, we have shown that "good training" can be equated with the terms of "vocational proficiency" and "matching". This combination, which aims both to impart employability skills and to facilitate integration into the company, provides the bedrock which enables skilled workers to act autonomously and independently. Works councils bring their influence to bear if they believe that these principles are in jeopardy. This makes an essential contribution to integrating apprentices into a company in respect of skills and socialisation.
\end{abstract}

Keywords: apprenticeship training within the dual system, Germany, social partnership, co-determination, work councils, training in SME

Introduction. Vocational education and training within the German dual system is characterised by its corporatist steering, its labour-market orientation and the link to the principle of the skilled occupation. The "concept of the skilled occupation" is anchored in the Vocational Training Act (Berufsbildungsgesetz, BBIG) and in the Crafts Code (Handwerksordnung, $\mathrm{HwO}$ ) and expressed in terms of recognised training occupations. The leitmotiv of apprenticeship training in Germany, i.e. the acquisition of "occupational proficiency" (berufliche Handlungsfähigkeit), represents a concept that goes beyond the transfer of skills, knowledge and qualifications. Vocational education and apprenticeship training aims to ensure that the teaching and learning process is geared towards the attainment of all-round holistic occupational proficiency and enables the apprentices/learners to obtain a qualification in a recognised training occupation. In this workbased learning context, the learning venue of the company takes on a central function in bringing about occupational proficiency. Apprentices spend three out of five days of the week in the company and two days at a part-time vocational school. 
Learning within the real work process and in authentic work situations is combined with formal learning at school. Vocational training standards thus represent a consistently defined understanding of quality pertaining to the content and institutional and organisational modalities of such training: how, within a systematic learning process, to prepare learners for the demands of a skilled occupation in the labour market (initial vocational education and training) and/or how to examine skills acquired in the course of work for the purposes of occupational advancement (upgrading/further training). This secures legal rights for all participants in initial vocational education and training: the companies, the apprenticesand, not least, employers and customers, who can claim entitlement to performance of a defined quality. Recognised training occupations are thus the result of (tripartite) negotiation processes between the state and the social partners. They are an expression of the plurality of coordination (steering) built into the German vocational education and training system; that is to say, collective responsibility for the vocational education and training system (ownership) materialises in these standards. But do ownership and commitment for commonly agreed vocational standards play a role on a company level? How do work councils especially in small and medium-sized companies assess the quality apprenticeship training and how do they contribute to it?

Materials. In Germany, companies with at least five employees have the statutory right to elect a representative body (works council). The proportion of staff represented by works councils in the public sector in 2016 was 91.0 percent. By way of contrast, the corresponding figure in the private sector economy was 41.2 percent. The proportion of companies with a works council grows in line with size. In 2016, only 9.0 percent of employees at companies with between five and 50 staff had a works council. In the case of companies with more than 50 employees, the proportion with a works council was 45 percent. A works council was in place at 88.5 percent of companies employing more than 500 staff (Federal Statistic Office 2018). The Labour Management Relations Act (Betriebsverfassungsgesetz BetrVG) grants works councils a graduated system of information, consultation, initiative and co-determination rights. With regard to apprenticeship training, the law stipulates that the works councils have the right "to exercise co-determination in the implementation of company based vocational education and training" ( $\$ 98$ BetrVG). Works councils are able to monitor apprenticeship training, to exert an active influence on the funding of training and to work with the employer to promote vocational education and training. Despite a multitude of studies on the effects of co-determination on company participation in training (Stegmaier, 2012) and on the costs of training (Kriechel et al., 2014), the question of influence of works councils on training quality was not addressed within the scope of quantitative investigations until 2018 (Koch, Mühlemann, Pfeifer, 2018).

Project objectives. The qualitative study investigated the understanding of training quality developed by works councils in SME, the mechanisms which bring about the causal correlations with the influence of works councils on training quality identified thus far (Koch, Mühlemann and Pfeifer 2018), and the conditions which are of relevance in this regard. In the core is the understanding of "apprenticeship training quality" that has been operationalised by the indicators of input (e.g. training regulations, training plan, aptitude of training staff), process (methodological and didactic implementation), output (examination success), transfer (of what has been learned to vocational practice) and outcome (sustainable usability of competencies acquired) and the actions of works councils performed within this context. The study aimed to reconstruct understandings of training and quality and the social processes at the company which are of significance to securing company training quality together with the conditions governing such processes.

Methods. In methodological terms, we based our study on an industrial sociology case study approach (Pongratz, Pfüger and Trinczek, 2010). Access to the field investigation took place via 13 expert interviews in six small and medium sized companies for the closer definition of hypotheses, which were examined in detail in four case studies. The first phase of research we talked to persons with responsibility for vocational training (trainers, human resources managers), members of the works council (BR), members of the Young People and Apprentice Council (JAV) from the following sectors: measurement technology, construction industry, wholesale trade, electrical engineering, trade and service for hard and software. Work councils were established in only two out of the six companies. We additionally conducted two meta-reflections with trade union secretaries, one from the Metal Union (IG Metall) and one from the Union for Public Services (Ver.di). The focus of the interviews was on the perception of apprenticeship training (How do you evaluate the apprenticeship training in this company?), linked in with the notion of quality (When is training "good"? What is necessary to 
make training "good"?). The role in which respondents saw their own function and the description of their role and tasks in apprenticeship training were further subjects of discussion. This first research phase insofar was aligned towards reconstructing the "experiences, perspectives, interpretations and relevance structures" of the respondents (Liebold and Trinczek, 2008). Based on first findings of the expert interviews and in line with a "most diverse" approach case studies were carried out in the automobile supplier industry and in local public transport in different regions (the Ruhr conurbation and non-urban areas of northern Germany). Due consideration was accorded to the characteristics of content reference, a combination of methods, multiperspectivity and openness (Pfüger et al., 2010). The result is four case studies which encompass companies in the automotive supplier industry with 490 and 600 employees respectively and public transportation firms with 75 and 100 members if staff. In both sectors forming the object of investigation, the purpose of training is to ensure a supply of skilled workers.

Results and discussion. The research phase comprising the expert interviews led to the following initial evaluations:

1. Across all the company interviews, the experts stated indicators that they assess as being essential to the implementation of apprenticeship training at their respective companies and given the general conditions that are in place. These are related to input aspects (equipment issues, staff, implementation of training), to the training process (level of assistance, measures to encourage motivation or training support measures) and to output/outcome (company and occupation related results such as completion of training, wage prospects and prospects for employment). Training quality was assumed to be in place if apprentices successfully complete training. This means that, as a category, it equates to examination success as illustrated by the following citations:

Head of Human Resources "Theoretically speaking, the success of training is measured by the final examination. If the final examination is good, then the training was good."

\begin{tabular}{ll}
\hline Trainer & "The main aim of training is to pass the skilled worker examination. Full \\
& stop."
\end{tabular}

2. A majority of the respondents refer to "training quality" in terms of the underlying occupational standard, thus also alluding to the objective of vocational education and training as described in $\S 1$ (3) of the Vocational Training Act (BBiG): "The purpose of vocational education and training is to impart the skills, knowledge and capabilities (employability skills) necessary in order to engage in a qualified occupational activity in a changing world of work within a regulated course of training. It should also enable trainees to gain the requisite occupational experience."

3. "The ability to perform vocationally" and "occupational proficiency" (berufliche Handlungsfähigkeit) describe the occupation-related outcome of training. This is directly linked with the companyrelated outcome of training, which can be paraphrased by the category of "attitude" (in the sense of being an individual match for the company). As the Head of Human Resources at company A puts it, this involves "knowing how the company ticks and what is important here". The Head of Human Resources at company $\mathrm{C}$ states, "We are seeking to strengthen internal values (...) by acting as role models (...). If we manage to do this, we will end up with a reliable and motivated member of staff who will enable us to survive against the tough competition we face."

3. "Good apprenticeship training" denotes a training organisation which is able to produce occupation-related (successful final examination) and company-related outcomes (match for the company) in an effective way against the background of specific operational requirements. Training is considered a pedagogical, educational and socialisational process within the company, which culminates in a personality which is in possession of employability skills, is a match for the company and identifies with its goals. "Good training can be described in really simply terms. (...) it is when a reliable member of staff is produced at the end with whom we are able to work together effectively and who provides the company with an output" (trainer at company B). 
The constructs of training quality and of "good implementation of training" formulated in the expert interviews were confirmed in the case studies. In the companies investigated in the case studies, the understanding of "good training" was also aligned to successful completion by trainees and thus to the training standard (recognised training occupation). This is circumscribed via the respective outcome expectations of the companies, of the staff providing training and of the works council. Depending on the interview subject, the emphasis was on economic or individual application contexts. Whereas management tends to view the objective of training in terms of producing qualified skilled workers and employees who are a good match for the company, trainers and the works council are more likely to accentuate the integration of young people into working life: "One focus is certainly on taking social responsibility into account. But another aspect that is, of course, much more important for us is to train our own staff and skilled workers in particular." (Works foreman)

"As we have said, there are people in society who take more time to develop. That's just the way it is. Actually, the occupation of machine and plant operator is ideal for pupils with a lower level of prior learning who may need this extra development time. (...). This is why we have chosen this occupation. If we have people or trainees who particularly stand out and if we are able to do so, then we offer training in the occupation of industrial mechanic. Maybe I can turn a certain trainee into a tool maker. Anything is possible. (...). This occupation is a good match for our production operations. We can pick up pupils from the schools. That's the way it works. People also need to be accommodated." (Head of Training)

"There are also people who have passed the lower secondary school leaving certificate and got good marks. We have to find some way or other of integrating them into our society. They may be glad that they have completed training and are then able to install and dismantle parts, which they can earn good money doing. We have split things up by reducing the number of tool makers whilst also placing a greater emphasis on production technology and machine and plant operators. We have done this in order to retain staff and secondly to offer an opportunity to the people in our society with a lower secondary school qualification so that they can be integrated into the work process. They can also be accommodated in the occupation in which they have done their training. This approach has, of course, also allowed us to raise the quality of our production staff." (Works council chair)

"Good training" is synonymous with the employability skills to be acquired in accordance with the Vocational Training Act. From a company point of view, it is essential that trainees learn over the course of training to integrate themselves into the firm's specific work regime and flexible working times and the respective social structure including specific work processes. The expert interviews had already indicated that works council activity in issues regarding training primarily concentrates on the areas of recruitment and subsequent permanent employment of apprentices, i.e. on performance of statutory rights of co-determination. This is confirmed by the case studies, in which the persons interviewed do not ascribe any effectiveness to the works council with regard to the structuring of training beyond the facts and circumstances relating to mandatory co-determination. However, the institutional function of the works council (performance of statutory rights of co-determination, "secondary power") is not called into question at any of the companies.

Conclusions. The works councils surveyed in the case studies concentrate their training-related activities on the facts and circumstances relating to co-determination statutorily made available to them. As far as training is concerned, respondents seldom report that they avail themselves of the right of initiative accorded to them. The result of company interest in "good training" (training as a means of ensuring a supply of skilled workers) and in combinations of stakeholders who work together in a spirit of trust ("We're not playing against each other. We play together in pursuit of the same goal, which is ultimately to achieve success at the company and secure our jobs (...)" company is that works councils at the companies investigated in the case studies do not see any need to intervene in the structuring of training. This may be one reason for the prevailing opinion expressed in the interviews both from the point of view of the employers and the works council members themselves that nothing about training would change if there were no works council. The case studies give rise to the supposition that works councils exert a stronger effect on securing training supply than on quality assurance or quality improvement. In all companies surveyed, they are demonstrably shown to take on a role as "advocates" of training, both at a personal level (conflicts in the workplace) and institutionally (securing the supply of training places at the company) and to act as a "firewall" in the case of any impending reduction in or cessation of training provision. 
All persons interviewed are of the view that the degree of influence exercised by works councils on the shaping of "good training" tends to be low. This is possibly due to the following causes.

(1) Ensuring a supply of skilled workers is the guiding principle. In areas where companies are only able to use the labour market to a limited extent to cover their requirement for qualified skilled workers, firms which provide their own training see this as an investment in the future. This investment motive extends beyond the primary interest of the companies to use their own training activities as a vehicle to produce qualified skilled workers with employability skills to encompass the idea of acquiring staff who are socialised within the firm and have learned to adapt to the respective work regime and social structure. Training which achieves this objective is automatically deemed to be of "good" quality. If the works council is also convinced that training is firmly established in the company's tradition, they perceive very little reason to intervene because their yardsticks and criteria for "good" training are also derived from the occupational profile or training regulations.

(2) Activities are embedded within the logic underlying the way in which the company is run. In exercising these rights and depending on their available resources, works councils exhibit a "broad and diverse understanding of their tasks [...] within company-based training which is not merely limited to a monitoring and protective function"
(Berger 2013, p. 20). They find themselves adopting a dual role: They are the elected representative body of the employees, but are at the same time committed to working towards the company goal and to cooperating with the employer in a spirit of trust. This is framed within the logic behind running the company, an area in which works council actions exercise significant co-determination. In the mediumsized enterprises offering apprenticeship training, "informal" control systems are described which are characterised by a "family-oriented" company climate in which everyone cooperates "openly and honestly" and in a "trusting and hand-in-hand manner" on training issues regardless of the hierarchy. The persons interviewed for the SME case studies expect that it will be possible to resolve conflict via the means of direct dialogue. Against this background works councils monitor the implementation of company-based training in their capacity as internal supervisors. As long as the companies themselves have a strong interest in "good" training and use this to ensure that apprentices successfully complete their training, the works councils see no reason to intervene. If general company conditions remain the same, the absence of a works council would possibly also have no impact on the success of training. However, if these general conditions alter and training is jeopardised at an institutional or individual personal level, works councils make a contribution towards securing training.

\section{List of references}

Berger, Klaus, Eberhardt, Christiane, Koch Benno, Mühlemann, Samuel, Pfeifer, Harald und Julia Raecke, 2019. Ausbildungsqualität in Betrieben: Welchen Beitrag leistet die betriebliche Mitbestimmung? In: Hans Böckler Stiftung, Working Paper Forschungsförderung, 130, April.

Berger Klaus und Christiane Eberhardt, 2019. Ausbildung und Mitbestimmung in klein- und mittelständischen Betrieben in Deutschland: Welchen Beitragen leisten Betriebsräte in Ausbildungsfragen? In: Franz Gramlinger, Carola Iller, Annette Ostendorf, Kurt Schmid \& Georg Tafner (Hrsg.): Bildung = Berufsbildung?! Beiträge zur 6. Berufsbildungsforschungskonferenz (BBFK). Wiesbaden, 1-4.

Berger, Klaus, 2013. Zur Handlungsorientierung von Betriebsräten in der betrieblichen Berufsausbildung [On the action orientation of works councils in company-based vocational education and training]. bwp@(Berufs- und Wirtschaftspädagogik-online [Vocational and Business Education - online], 25, pp. 1-22.

Bundesinstitut für Berufsbildung [Federal Institute for Vocational Education and Training] (Ed.), 2018. Datenreport zum Berufsbildungsbericht 2018 [Data Report to accompany the 2018 Report on Vocational Education and Training]: Informationen und Analysen zur Entwicklung der beruflichen Bildung [Information and analyses on the development of vocational education and training]. Bonn.

Bundesministerium für Arbeit und Soziales (BMAS) [Federal Ministry for Labour and social issues], 1995. Mitbestimmung - eine gute Sache. Alles über die Mitbestimmung und ihre rechtlichen Grundlagen, Berlin. Avialable at: <https://www.bmas.de/SharedDocs/Downloads/DE/PDF-Publikationen/a741mitbestimmung-ein-gutes-unternehmen.pdf? blob=publicationFile $>$ [Accessed 23 September 2019]. 
HansBöckler-Stiftung (HBS): Betriebliche Mitbestimmung in Europa. Avialable at: $<$ http://de.workerparticipation.eu/Nationale-Arbeitsbeziehungen/Quer-durch-Europa> [Accessed 23 September 2019].

Koch, Benno; Mühlemann, Samuel and Harald Pfeifer, 2018. Do works councils improve the quality of apprenticeship training in Germany? Avialable at: <http://conference.iza.org/conference_files/EmRep_2018/pfeifer_h4414.pdf> [Accessed 10 August 2018].

Kriechel, Ben /Mühlemann, Samuel /Pfeifer, Harald and Miriam Schütte, 2014. Works Councils, Collective Bargaining, and Apprenticeship Training - Evidence From German Firms. Industrial Relations, 53 (2), s. $199-222$.

Liebold, Renate/Trinczek, Rainer, 2009. Experteninterview. In: Kühl, Stefan et.al. (Hrsg.) Handbuch Methoden der Organisationsforschung: Quantitative und qualitative Methoden. Wiesbaden, s. 32-56.

Pflüger, Jessica, Pongratz, Hans, J. and Rainer Trinczek (2010): Fallstudien in der deutschen Arbeitsund Industriesoziologie. In: Pongratz/Trinczek (Hg.): Industriesoziologische Fallstudien. Entwicklungspotenziale einer Forschungsstrategie. Berlin, s. 23-70.

Stegmaier, Jens, 2012. Effects of works councils on firm-provided further training in Germany. British Journal of Industrial Relations, 50(4), pp. 667-689.

Windeler, A., Sydow, J., 2001. Strukturationstheoretische Analyse industrieller Beziehungen - Soziale Praktiken der Arbeitsregulation im Fokus [Structuration theory analysis of industrial relations - focus on social practices of work regulation]. In: Abek, J., Sperling, H. J., eds.: Umbrüche und Kontinuitäten. Perspektiven nationaler und internationaler Arbeitsbeziehungen [Upheavals and continuities. Perspectives of national and international work relations]. Munich and Mehring, pp. 31-48.

Received: 05 September 2020

Accept: 25 September 2020 